'Differences in call centre agents' perception of their job characteristics, physical work environment and wellbeing"

\begin{tabular}{ll} 
AUTHORS & $\begin{array}{l}\text { Noleen Miller } \\
\text { Rozenda Hendrickse }\end{array}$ \\
& $\begin{array}{l}\text { Noleen Miller and Rozenda Hendrickse (2016). Differences in call centre agents' } \\
\text { perception of their job characteristics, physical work environment and wellbeing. } \\
\text { Problems and Perspectives in Management, 14(1), 51-63. } \\
\text { doi:10.21511/ppm.14(1).2016.06 }\end{array}$ \\
\hline ARTICLE INFO & http://dx.doi.org/10.21511/ppm.14(1).2016.06 \\
\hline DOI & Wednesday, 02 March 2016 \\
\hline RELEASED ON & "Problems and Perspectives in Management" \\
\hline JOURNAL & LLC “Consulting Publishing Company "Business Perspectives" \\
\hline FOUNDER &
\end{tabular}

NUMBER OF REFERENCES

0

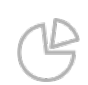

NUMBER OF FIGURES

0

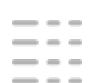

NUMBER OF TABLES

0

(C) The author(s) 2023. This publication is an open access article. 
Noleen Miller (South Africa), Rozenda Hendrickse (South Africa)

\title{
Differences in call centre agents' perception of their job characteristics, physical work environment and wellbeing
}

\begin{abstract}
Orientation: job characteristics and physical work environment of call centres have an impact on the wellbeing of call centre agents.

Research purpose: the aim of this study is to determine whether there are differences in male and female call centre agents' perception of their job characteristics, physical work environment and wellbeing. The study also aims to investigate whether there is a significant relationship between the wellbeing problems encountered by call centre agents and the job characteristics and physical work environment factors.
\end{abstract}

Motivation for the study: wellbeing in call centres is a concern and therefore necessitates a study in understanding the factors of the work environment that negatively impact the wellbeing of call centre agents.

Research design, approach and method: a quantitative research approach was employed to gather the data for the study, utilizing a structured questionnaire. The sample $(n=275)$ consisted of call centre agents from four companies situated in the Cape Metropole.

Main findings: call centre agents had the same perceptions of their job characterises. Differences in perception were found with the physical work environment and wellbeing. Significant relationships between job characteristics, physical work environment and wellbeing were found.

Contribution/value-add: the study contributes to the literature and knowledge of the workplace environment and wellbeing of call centre agents.

Keywords: call centre, call centre agent, physical work environment, physical wellbeing, emotional wellbeing, performance management, autonomy, stress, burnout, musculoskeletal disorder.

JEL Classification: M1.

\section{Introduction}

The call centre industry is one of the fastest growing industries globally (Abrahams, 2008) and it has become an important source for businesses to communicate with customers, whether information is shared (inbound) or by means of telesales (outbound) (White \& Roos, 2005). The work environment of call centres has become multichannelled communication centres that offer fax, email, web chat and internet as communication channels for customers (Banks \& Roodt, 2011).

Call centres are an alternative means of contact between the customer and the organization and it eliminates the high costs of one-to-one interaction (Möller, Crous \& Schepers, 2004). Call centres are important constituents of services that organizations offer customers by means of solving problems, resolving complaints and providing information (Lywood, Stone \& Ekinci, 2009). Whilst call centres are offering companies benefits in terms of cost savings and generate huge amounts for the economy, not enough emphasis has been placed on the job characteristics and physical work

(c) Noleen Miller, Rozenda Hendrickse, 2015.

Noleen Miller, M.Tech. Business Administration, Administrator, Cape Peninsula University of Technology, South Africa.

Rozenda Hendrickse, Ph.D., Associate Professor in Public Management, Cape Peninsula University of Technology, South Africa. environment of these call centres and how this impacts on the wellbeing of call centre agents. The call centre industry has suffered from a poor reputation of low pay, monotonous work, high job demand, low control, limited social support and few opportunities for participating and acquiring new skills and training (Anderson \& Jansson, 2006).

Research purpose and objectives. Against the preceding background it is evident that call centres are an important source of communication with customers. However, customers are becoming more demanding and less satisfied with the service they receive from call centres. The agent on the other hand, gets caught up between conflicting demands of efficiency and quality service (Millard, Alcock \& Butterworth, 2006). Due to the importance of these agents to the organization, it is important to establish their perceptions of the working environment and how it affects their wellbeing. Until recently most studies on the perception of the working environment in call centres have been based on the collective workforce (Hingst, 2006; Hauptfleish \& Uys, 2006; \& Charbotel et al., 2009). However, perception of the work environment may differ between genders.

In view of this, this research aims to explore whether call centre agents' gender predicts how they perceive the call centre working environment and 
whether this environment affects their wellbeing. While both males and females are employed in call centres, this industry is predominantly occupied by female agents (Barrett \& Davidson, 2006).

Research questions. Given the stated problem, two research questions were identified:

Research question 1: Is there a significant difference between male and female perceptions of job characteristics, physical working environment and emotional and physical wellbeing in call centres?

Research question 2: Is there a significant relationship between the wellbeing problems encountered by the call centre agents and the job characteristics and physical working environment?

Research objectives. The objective of this study is to create awareness to call centre agents of the factors that may trigger certain health problems in the workplace and to provide call centre management with suggested measures to improve the work environment in call centres.

Contribution to field. The study contributes to the literature and knowledge of the workplace environment and wellbeing of call centre agents.

A theoretical overview of job characteristics, physical work environment and wellbeing in call centres will follow.

\section{Literature review}

1.1. Job characteristics in call centres. Call centre agents have limited autonomy over work tasks and their working environment; they cannot use their discretion over the methods they use, how tasks are completed and the time allocation of their work (Comcare, 2006). The work tends to be monotonous and repetitive, since call centre employees are not given challenging tasks or allowed to set their own goals (Dreery \& Kinnie, 2004).

Dean \& Rainnie (2008) found that efficiency demands of call centre work are linked to performance in terms of time pressures associated with workload. Call centre agents are often required to achieve targets based on key performance indicators such as abandoned call rates and the average speed of answering a call.

Performance monitoring focuses on numbers of calls and performance, and provides data on the number of calls waiting, the proportion of calls answered, the average call duration, and the customer waiting time (Banks \& Roodt, 2011). The information gained from the monitoring process can be used for disciplinary purposes, and is perceived as threatening, because it directly affects remuneration. Performance monitoring is viewed as a job demand and is associated with negative employee wellbeing (Visser \& Rothmann, 2008).
In many instances call centre agents have no opportunity to use their skills as they are only allowed to do a small part of the work and the rest is passed on to the back office where specialists will complete the queries (Visser \& Rothman, 2008). They have limited skills and task variation, as call centre work usually requires agents to sit at their workstations and use the telephone for most of their job functions. Call centre tasks have low complexity, owing to constrained and detailed procedures (Aksin, Armony \& Mehrotra, 2007). In a study conducted by Norman, Tornquist \& Toomingas (2008) they found that call centres with low complexity tasks seemed to be more short-cycled, repetitive and standardized and that call centre agents in these call centres were paid lower salaries.

Call centre agents receive feedback on performance monitoring via performance appraisal systems by means of grading or scoring work categories (Comcare, 2006). According to Lunenberg (2011) performance varies and for employees to make appropriate adjustments they need to know how they currently performing.

Task significance may play an important role in increasing job performance if employees who find their work more meaningful (Grant, 2008).

Taken these job characteristics into consideration, male and female employees tend to value job characteristics and the intrinsic and extrinsic rewards that come with the job differently (Huang \& Gamble, 2015)

1.2. Physical work environment in call centres. Open plan office layouts are favored by many call centre organizations as the layout is flexible, and reorganization of teams can easily be reflected by reorganizing the layout of workstations. However, openplan offices are associated with employee stress, poor co-worker relations and reduced satisfaction with the physical environment (Paul, 2012).

Indoor temperature and air quality is a primary characteristic of the physical working environment and they are strongly influenced by the architectural solution of a building as well as workstation design (Danielsson, 2010). The indoor temperature affects several human responses, including thermal comfort, perceived air quality, sick building syndrome and performance at work (Seppänen, Fisk \& Lei, 2006). High workstation panels are related to physical and visual discomfort. Employees should be able to adjust the interior of their workstation features, which will allow them more space in arranging furniture and equipment and increase their storage capacity (Knoll, 2010). This will decrease the stress and increase job satisfaction (Knoll, 2010).

1.3. Wellbeing in call centres. Although call centres enhance customer relations, improving efficiency and 
are cost effective to businesses, call centre agents experience stress due to excessive workload, time pressures to reach targets, abusive customers and the fact that they need to work night shift (Latha \& Panchanatham, 2010). Emotional, mental and physical exhaustion caused by excessive and prolonged stress can lead to burnout (Sowmya \& Panchanatham, 2011). Elements of work and the working environment can cause job stress that stem from the work content (what the job involves) and from the work context (the psychosocial work environment) (Comcare, 2006).

Research has shown that low job control increases the risk of impaired wellbeing (Patterson, Warr \& West, 2004) and health (Elfering, Semmer \& Grebner, 2005). Spriggs \& Jackson (2006) found that employees who experience greater prescriptive dialogue and intensive performance monitoring show high levels of stress. High performance targets are set for agents to take an allocated number of calls per day. Increased time pressures and work demand is positively related to stress (Palm, 2012) as well as monotonous and less challenging work (Shah, 2013). When these work demands are high and no co-worker and supervisor support are received it leads to high levels of job stress (Deveroux, Hastings \& Noone, 2009).

Research shows that there is a link between increasing job demand in the form of work overload and the development of burnout (Schaufeli, Bakker \& Van Rhenen, 2009). These authors found that when job demands (work load, emotional demands) increase and job resources decrease (autonomy, feedback, social support and opportunities to learn) that burnout occurs. This creates internal conflict between management and call centre agents (Visser \& Rothman, 2008) and contradictory pressures on the call centre agents, which lead to emotional exhaustion. Call centre work is routine, with a lack of skill variety which makes the job repetitive in nature (Visser \& Rothmann, 2008). Encouraging relationships between call centre agents, co-workers and supervisors in call centres may be beneficial; however supervisors can either be a source of support or strain for call centre agents (Cappelli, 2008). High levels of co-worker and supervisor support can protect employees from emotional exhaustion when faced with high work demands (Salahian, Oreizi, Abedi \& Soltani, 2012).

Call centre agents are faced with the task of making or receiving telephone calls and simultaneously using computer equipment where information is displayed on visual display units (VDU) during calls. There is no research evidence that display screen equipment (DSE) or visual display units (VDUs) can cause permanent eye damage or disease, but they can cause visual fatigue, eye discomfort and headaches from intensive use (Amicus, 2006; Comcare, 2006).

Call centre agents are among the workers who rely on their voices to carry out their work and this increases the risk of voice disorders due to workrelated excessive oral communication (Vilkman, 2004). Bacterial transfer increases when headset/earphones are frequently used and the chances of bacteria being transferred increases when headsets/earphones are shared which causes ear infections (Mukhopadhyaya, Basak, Gupta, Chawla \& Brairy, 2008). By cleaning the headsets/earphones with alcohol reducing the risk infection rate (Mukhopadhyaya et al., 2008). The most common auditory problems are caused by acoustic shock which is a sudden spike in noise levels from a change in volume of the headset, background noise from incoming calls and other factors in the workplace (NIOSH, 2011). Repeated exposure to acoustic shock can lead to hearing loss and tinnitus (NIOSH, 2011).

Call centre agents develop musculoskeletal disorders (MSD) through the repetitive movements and prolonged sitting postures while simultaneously being expected to communicate with customers efficiently, adhere to time pressures and have their performance monitored (Norman, Tornquist \& Toomingas, 2008). Physical workplace factors (e.g. posture, prolonged static muscle load, workstation set up, high temperature, VDUs and insufficient lighting) are risk factors for MSDs (Da Costa \& Vieira, 2010). MSDs can be caused by the combination of high repetitiveness in the fingers and wrist, the static loading on the thumb to grip the mouse, and the extension and deviation of the wrist (Wahlström, 2005).

\section{Gender differences in call centre work environment}

Females dominate the call centre industry as they have the interpersonal skills to communicate with customers (Bonds, 2006). However research conducted by Korvajärvi (2009) differs that men are often better at call centre work because their personalities are more suited for the work. Although the same type of work is performed and the work environment is the same, male and females often perceive their working environment differently. Employment in emotional demanding work or work where you work directly with people is more common amongst females than males. In a study on call centres by De Smet et al. (2005) it was determined that men perceive high job control at work than females. They also found that job strain was more prevalent in females than males. Physical health problems with regards to 
musculoskeletal problems, optical health problems, auditory and vocal health problems are experienced more by female call centre agents than males (Subbarayalu, 2013).

\section{Research design}

3.1. Research approach. In terms of achieving the objectives of this study a quantitative research method was used.

3.2. Research method. 3.2.1. Research participants. The combined target population of all four participating call centres was 760. A sample size of 200 was determined by using the Roasoft ${ }^{\circledR}$ Incorporated calculation tool and although the aforesaid sample size was adequate for this study, there was a response rate of 275 call centre agents. The majority of the call centre agents who participated were female, $61.8 \%$ compared with $38.2 \%$ of male participants. The age of the call centre agents varied from 21 years to 65 and older.

3.2.2. Measuring instruments. A structured questionnaire was used for the survey study so that statistical data could be easily analyzed. The structured questionnaire was developed using existing measuring instruments used in previous research studies and discussed below. The demographic section comprised of basic information regarding gender, race, age, industry, years of employment, shifts and working hours, smoking and whether they exercised.

Job diagnostic survey (JDS): Questions relating to job characteristics and significance of the work were based on the JDS development by Hackman and Oldham in 1975. In this study only the job dimensions and critical psychological states sections of the JDS questions were used. The reliabilities are 0.73 for the job dimensions section and 0.73 for the critical psychological states section.

Social support: Questions relating to social support were based on the instrument developed by Caplan, Cobb, French, Van Harrison \& Pinneau in 1975 (Fields, 2002). An adjustment was made to the instrument by omitting "spouse, friends and relatives" as the focus would be on people in a work situation only. A five-point scale was used where the lowest is represented by 1 "Don't have any such person" and the highest 5 "Very much". The reliability for the scale is 0.82 .

Job demands: Questions were based on the instrument developed by Karasek in 1979 (Fields, 2002). Only the section on job demand was used. A five-point scale was used where the lowest is represented by 1 "Never" and the highest by 5 "Extremely often". The reliability for the scale is 0.82 .
Performance monitoring: This study used the questions based only on performance monitoring in the Sprigg et al. (2003) study. The reliability for the scale is 0.71 .

Physical work environment: Questions relating to the physical work environment were based on the instrument developed by Sprigg et al. (2003). A five point likert scale was used where the lowest is represented by 1 "Very dissatisfied and the highest by 5 "Very satisfied". The reliability is 0.93 .

Oldenburg burnout inventory (OBI): Emotional wellbeing questions relating to burnout were measured using the OBI. A five point Likert scale was used where the lowest is represented by 1 "Strongly disagree" and the highest 5 "Strongly agree". The reliability for the OBI scale is 0.87 .

Vocal health, optical health and auditory health: Questionnaires relating to these health issues were based on the questions developed by Sprigg et al. (2003). A 5-point response scale was used for the vocal and optical health questions, ranging from 1 being the lowest "Never" to the highest being 5 "All of the time". A 5-point Likert response scale will be used for the auditory health questions, ranging from 1 being the lowest "Never/rarely" to the highest being 5 "Constantly". The reliabilities are 0.87 for vocal health, 0.90 for optical health and 0.81 for auditory health.

Job stress: Questions relating to job stress were measured using the "Somatic Complaints" section of the NIOSH Generic Job Stress Questionnaire. A five point Likert scale was used where the lowest is represented by 1 "Never" and the highest by 5 "Very often". The reliability for the somatic complaints is 0.93 .

Musculoskeletal disorder (MSD): Questions were based on the Cornell Musculoskeletal Discomfort Questionnaire (CMDQ) developed by Hedge (1994). The reliabilities are 0.89 for MSD Section 1, 0.86 for MSD Section 2 and 0.87 for MSD Section 3.

3.2.3. Research procedure. The Surveymonkey software tool was used to compile the structured questionnaire. An outline of the purpose of the study, the importance of completing the questionnaire as well as the procedures for completing the questionnaire was explained to the call centre agents in a cover letter. Access to the questionnaire was via an electronic link inserted in the cover letter.

3.2.4. Statistical analysis. The data were interpreted using the SPSS (Statistical Package for Social Sciences). The demographical data were not interpreted by SPSS and were analyzed using the Surveymonkey tool. 
For the purpose of this study, a factor was conducted on the questions pertaining to the physical environment and job stress. The type of factor analysis used in this study is principle component analysis (PCA). In order to identify the factors, the Varimax rotation method was performed to identify meaningful factors. An independent sample test was conducted in order to determine whether two groups differ significantly or not. The independent sample t-test was conducted to establish whether the male and female respondents differed significantly with regard to their perceptions of job characteristics, physical work environment, and wellbeing. In this study, the Pearsonproduct moment correlation coefficient was used to test for relationships between job characteristics, physical work environment and wellbeing.

\section{Results}

4.1. Factor analysis. A factor analysis was conducted to answer the research question which was concerned with the factors in the workplace environment that contribute to emotional and physical wellbeing. Although 23 factors were initially extracted in SPSS, only five factors met the cut-off criteria. A five-factor analysis was conducted explaining co-variation amongst observed variables. The results are presented in eigenvalues, extraction sums of squared loadings and rotation sums of squared loadings. The percentage of variance column indicates how much of the total variability in all 23 variables can be accounted for by each of these factors. Five factors were extracted and grouped under workstation (factor 1), temperate and air quality (factor 2), workspace and office layout (factor 3), maintenance and conditions of chairs (factor 4) and storage (factor 5). These results are presented in Table 1.

Table 1. Total variance physical work environment

\begin{tabular}{|c|c|c|c|c|c|c|c|c|c|}
\hline \multirow{2}{*}{ Component } & \multicolumn{3}{|c|}{ Initial eigenvalues } & \multicolumn{3}{c|}{ Extraction sums of squared loadings } & \multicolumn{3}{c|}{ Rotation sums of squared loadings } \\
\cline { 2 - 11 } & Total & $\%$ of variance & Cum \% & Total & $\%$ of variance & Cum \% & Total & $\%$ of variance & Cum \% \\
\hline 1 & 9.070 & 39.434 & 39.434 & 9.070 & 39.434 & 39.434 & 3.900 & 16.955 & 16.955 \\
\hline 2 & 2.192 & 9.532 & 48.967 & 2.192 & 9.532 & 48.967 & 3.592 & 15.618 & 32.574 \\
\hline 3 & 1.686 & 7.331 & 56.298 & 1.686 & 7.331 & 56.298 & 3.134 & 13.628 & 46.201 \\
\hline 4 & 1.401 & 6.092 & 62.390 & 1.401 & 6.092 & 62.390 & 3.000 & 13.045 & 59.246 \\
\hline 5 & 1.007 & 4.376 & 66.766 & 1.007 & 4.376 & 66.766 & 1.730 & 7.520 & 66.766 \\
\hline
\end{tabular}

Although 17 factors were initially extracted in SPSS, only three factors met the cut-off criteria. A three-factor analysis was conducted, explaining covariation amongst observed variables. The results are presented in eigenvalues, extraction sums of squared loadings and rotation sums of squared loadings. The percentage of variance column indicates how much of the total variability in all 17 variables can be accounted for by each of these factors. Three factors were extracted from and were grouped under anxiety (factor 1), acute stress (factor 2), and physical and behavioral stress symptoms (factor 3 ). These results are presented in Table 2.

Table 2. Total variance job stress

\begin{tabular}{|c|c|c|c|c|c|c|c|c|c|}
\hline \multirow{2}{*}{ Component } & \multicolumn{3}{|c|}{ Initial eigenvalues } & \multicolumn{3}{c|}{ Extraction sums of squared loadings } & \multicolumn{3}{c|}{ Rotation sums of squared loadings } \\
\cline { 2 - 21 } & Total & $\%$ of variance & Cum \% & Total & $\%$ of variance & Cum \% & Total & $\%$ of variance & Cum \% \\
\hline 1 & 8.360 & 49.174 & 49.174 & 8.360 & 49.174 & 49.174 & 4.404 & 25.908 & 25.908 \\
\hline 2 & 1.512 & 8.894 & 58.068 & 1.512 & 8.894 & 58.068 & 3.377 & 19.864 & 45.772 \\
\hline 3 & 1.163 & 6.843 & 64.911 & 1.163 & 6.843 & 64.911 & 3.254 & 19.139 & 64.911 \\
\hline
\end{tabular}

2. t-test. A t-test was conducted to answer the first research question on whether there is a significant difference between the means of male and female levels of perceptions towards their job characteristics, physical working environment and wellbeing.

Table 3 presents the t-test results of perceptions on job characteristics. No significant differences were found related to job characteristics.

Table 3. t-test for job characteristics

\begin{tabular}{|l|c|c|c|}
\hline & $t$ & $d f$ & $p$-value (2-tailed) \\
\hline Skill variety & 1.43 & 273 & .15 \\
\hline Job feedback & .63 & 242 & .53 \\
\hline Task variety and identity & -.26 & 242 & .80 \\
\hline
\end{tabular}

\begin{tabular}{|l|c|c|c|}
\hline Agency feedback & .183 & 226 & .86 \\
\hline Task significance & 1.19 & 242 & .24 \\
\hline Autonomy & .59 & 242 & .55 \\
\hline Supervisory support & .26 & 222 & .79 \\
\hline Co-worker support & -.26 & 222 & .80 \\
\hline Job demand & -1.01 & 219 & .32 \\
\hline Performance monitoring & -.61 & 218 & .54 \\
\hline
\end{tabular}

Table 4 presents the t-test results of perceptions on physical work environment. Significant differences were found with temperature and air quality $t(194),=2.4, p=.018<.05$, workspace and office layout $t(212),=2.9, p=.005<.05$ and maintenance and adjustability of chairs and screens $t(183),=2.0, p=.048<.05$. 
Table 4. t-test for physical work environment

\begin{tabular}{|l|c|c|c|}
\hline & $t$ & $d f$ & $\begin{array}{c}p \text {-value } \\
(2 \text {-tailed })\end{array}$ \\
\hline Workstation & .78 & 214 & .44 \\
\hline Temperature and air quality & 2.4 & 194 & .018 \\
\hline Workspace and office layout & 2.9 & 212 & .005 \\
\hline $\begin{array}{l}\text { Maintenance and adjustability of chairs and } \\
\text { screens }\end{array}$ & 2.0 & 183 & .048 \\
\hline Storage & 1.3 & 214 & .210 \\
\hline
\end{tabular}

Table 5 presents the t-test results of perceptions on wellbeing. There is a statistically significant difference in exhaustion $t(190)=2.0, p=.047<.05$, vocal health $t(209)=-2.1, p=.04<.05$, optical health $t(208)=$ $-2.7, p=.007<.05$, auditory health $t(190)=-2.3$, $p=.022<.05$, acute stress $t(164)=-2.5, p=$ $.013<.05$, physical and behavioral stress symptoms $t(173)=-2.2, p=.029<.05$ and musculoskeletal health problems $t(201)=-1.9, p=.058>.05$.

Table 5. t-test for wellbeing

\begin{tabular}{|l|c|c|c|}
\hline & $t$ & $d f$ & $\begin{array}{c}p \text {-value } \\
(2 \text {-tailed })\end{array}$ \\
\hline Exhaustion & 2.0 & 190 & .047 \\
\hline Disengagement & .69 & 210 & .49 \\
\hline Vocal health & -2.1 & 209 & .04 \\
\hline Optical health & -2.7 & 208 & .007 \\
\hline Auditory health & -1.5 & 208 & .141 \\
\hline Anxiety & -2.3 & 190 & .022 \\
\hline Acute stress & -2.5 & 164 & .013 \\
\hline Physical and behavioral stress symptoms & -2.2 & 173 & .029 \\
\hline MSD & -1.9 & 201 & .058 \\
\hline
\end{tabular}

4.3. Pearson correlation effect. The correlation analysis conducted to answer the second research question by assessing whether significant relationships exist between job characteristics, physical work environment and the wellbeing problems encountered by the call centre agents. These correlations were testing with all job characteristics, only that physical work environment that was different and the difference in wellbeing problems (see Table 6 Appendix).

A low negative correlation was found between skills variety and exhaustion $r=-0.29, p=<0.001$. Low negative correlations were also found between skills variety and optical health $r=-0.22 . p=<0.001$; acute stress $r=-0.22, p=<0.001$ and physical and behavioral stress symptoms $r=-0.20, p=<0.001$.

Moderate positive correlations were found between autonomy between workspace and office layout $r=0.25, p=<0.001$. A low negative correlation was found between autonomy and exhaustion $r=-0.39$, $p=<0.001$. Low negative correlations were also found between autonomy and optical health $r=-0.24, p<0.001 ;$ acute stress $r=-0.28$, $p<0.001$; physical and behavioral stress symptoms $r=-0.27, p<0.001$ and MSD $r=-0.21, p<0.001$.

Low negative correlations were found between supervisory support and exhaustion $r=-0.31$, $p=<0.001$; and optical health $r=-0.25, p=<0.001$.

Low negative correlations were found between coworker support and exhaustion $r=-0.22, p=<0.001$; physical and behavioral stress symptoms $r=-0.21$, $p=<0.001$ and MSD $r=-0.21, p=<0.001$.

Low negative correlations were found between job demand and workspace and office layout $r=-0.31$. A low positive correlation was found between job demand and exhaustion $r=0.37, p=<0.001$, optical health $r=0.21, p=<0.001$, auditory health $r=0.24$, $p=<0.001$, physical and behavioral stress symptoms $r=0.21, p=<0.001$ and MSD $r=0.24, p=<0.001$.

Low positive correlations were found between performance monitoring and vocal health $r=0.19$, $p=<0.0001$ as well as auditory health $r=0.29$, $p=<0.0001$. Low negative correlations were found between performance monitoring and workspace and office layout $r=-0.15, p=<0.0001$.

Low positive correlations were found between workspace and office layout and job feedback $r=0.20$, $p=<0.001$; autonomy $r=0.24, p=<0.001$; coworker support $r=0.25, p=<0.001$. Moderate positive correlations were found between workspace and office layout; temperature and air quality $r=0.44$, $p=<0.001$ and maintenance and adjustability of chairs and screens $r=0.41, p=<0.001$. Low negative correlations were found between workspace and office layout and job demand $r=-0.32, p=<0.001$, exhaustion $r=-0.25, p=<0.001$; acute stress $r=-0.24, p=<0.001$; physical and behavioral stress symptoms $r=-0.23, p=<0.001$ and MSD $r=-0.31$, $p=<0.001$.

A low positive correlation was found between maintenance and adjustability of chairs and screens and autonomy $r=0.17, p=<0.001$. Moderate positive correlations were found between maintenance and adjustability of chairs and temperature and air quality $r=0.38, p=<0.001$ and workspace and office layout $r=0.41, p=<0.001$. Low negative correlations were found between maintenance and adjustability of chairs and screens and job demand $r=-0.19, p=<0.001$; vocal health $r=-0.23, p=<0.001$; auditory health $r=-0.19, p=<0.001$; acute stress $r=-0.25$, $p=<0.001$ and MSD $r=-0.24, p=<0.001$.

\section{Discussion}

The aim of this study was to assess the call centre agents' perceptions of their job characteristics and physical work environment and to determine 
whether there is a relationship between what they perceive and their wellbeing.

Both males and females felt that they have very little to moderate autonomy and that the work is fairly standardized and not under their control but that they can make some decisions about their work. Benner, Lewis \& Omar (2007) found that call centre agents have discretion in their interaction with customers and how they handle customer complaints. However in a study conducted by Garcia \& Archer (2012) they found that the working conditions in call centres affect the opportunities that call centre agents have to organize their own work and diminish their sense of freedom for decision making. Call centre agents can make decisions and use their discretion in the way they solve client queries and problems. However they still do not have control over their working hours as indicated in the demographics, the results from the job demands as well as performance monitoring sections indicate that call centre agents do not have control over performance targets, call queues, performance monitoring and the little discretion that they have to make decision needs to be in line with the organizations goals.

Males and females felt that the job requires the use of a variety of skills to perform the work. Call centre agents need to have good communication skills in dealing with customers, they need to integrate the use of VDU, computer and telephone system simultaneously (Suff, Reilly \& Mercer, 2005) and have the necessary product knowledge. Lloyd \& Payne (2008) argue that unless skill is not linked to technical knowledge and competence then it is meaningless in the call centre industry. Good interpersonal-, communication-, computer skills and product knowledge is needed to work as a call centre agent; however the skills required is not complex and scarce that a university or college qualification is needed to perform the work. This relates to the findings by Benner, Lewis \& Omar (2007) that call centre agents only need a matric qualification.

Males and females felt that there is very little variety in the job and that the work is simple and repetitive. They felt that the work allows them to finish a set piece of work from beginning to end. These findings correspond with that of Visser \& Rothman (2008) that call centre work is highly routinized and repetitive in nature and the division of labor only allow the call centre agents to do a small piece of the work thereafter it is transferred to the back office employees to finalize (Visser \& Rothman, 2008). Call centre agents often receive the same type of calls on a daily basis making the work fairly standardized, monotonous and repetitive. Although call centre agents are allowed to complete their work from beginning to end this contributes to meaningfulness where they can see the outcomes of their work; however this can be difficult to achieve as added pressure are placed on the employees considering the high job demand and time pressure to complete their work.

Males and females felt that their job is significant and that their ability to perform their job well will assist others. Effective communication can lead to employee satisfaction and engagement. Employees who receive feedback from management on how significant and successful their work is and how it contributes to the success of the organization will continue to broaden their thinking about how they can do more to contribute to customer satisfaction (Carrig \& Wright, 2006). Call centre agents who experience some form of responsibility in the work they deliver and knowing that they make a difference in the lives of others would increase the purpose of their work.

Males and females felt that working in a call centre is demanding and that the excessive workload requires them to work hard and at a fast paste. They also felt that they do not have enough time to successfully complete their work. Call centres are highly targetfocused environments where pressure is placed on call centre agents to meet both individual and team-based targets (Hannif, McDonnell, Connel \& Burgess, 2010). The findings of this study also showed that call centre agents felt that they had conflicting demands of delivering quality customer service and taking a high quantity of calls. This is consistent with that of Holman, Wall, Clegg, Sparrow \& Howard (2005) that call centre agents have to deal with the conflicting demands of quality vs quantity in every call they take.

Males and females felt that they are constantly performance monitored on their calls and that their log in and out times. They were also monitored on the duration of time spent on the phone as well as the time lags between calls. These findings correspond with that of Banks and Roodt (2011) that performance monitoring in call centres measure the number of calls waiting, quantity of calls answered, average call duration and the customer waiting time. Performance monitoring is often used to measure the efficiency of the service rather than the quality of customer service; thus putting an added pressure on the call centre agent to perform faster to be able to take more calls.

$22 \%$ of the call centre agents felt that their supervisors do not go out of their way to make work life easier. The study also found that $19 \%$ of call centre agents felt that they do not get support from their supervisors when the working conditions get tough. These findings correspond with that of Hauptfleich \& Uys (2006) that management does 
not always deliver on promises and occasionally turn their backs on consultants rather than assisting them when problems occur. Call centre agents who get the necessary support at work will feel that they are valued within the organization.

Women were less satisfied than men with regard to the temperature and air quality in their call centres. Poor air quality in the workplace can negatively impact mental wellbeing, also resulting in "sick building syndrome", where employees continuously breathe recycled air as they do not get sufficient fresh air (Cooper, Boyko \& Codinhoto, 2008). Although most call centres have air conditioners, these air conditioners are centralized throughout the floor and therefore fresh air can be an asset. These offices are fully occupied and the layout forces call centre agents to work in close proximity to one another, which could be a health risk. Inadequate ventilation and temperature could contribute to tiredness, lethargy, and irritated eyes. Not all call centre agents, as the findings have shown, would be satisfied with the temperature and air quality owing to individual differences in the level of comfort. Women were less satisfied with their workspace and office layout than men. The findings show that $34 \%$ of women were dissatisfied with their storage space for work documentation, while 39\% were dissatisfied with their storage space for personal items. Call centre agents often complain about the lack of storage space for personal and work-related items. According to Herman Miller Inc. (2007), employees want some control over their workspace to imprint their personalities and communicate who they are to their co-workers. Herman Miller Inc. (2007) states having control over the workspace fosters better performance and retention, and makes employees feel more comfortable in their working environment.

Women were less satisfied with the maintenance and adjustability of chairs and screens. The findings show that $32 \%$ of women were dissatisfied with the conditions of the chairs, while $35 \%$ were dissatisfied with the maintenance standards of the chairs. Toomingas and Gavhed (2008) note that office furniture and equipment of high quality are needed in call centres, but that it is important that they are correctly positioned and adjusted to allow good working postures and a lower risk of MSD. The findings of this research agree with those of Toomingas and Gavhed (2008), in that good-quality furniture and chairs are needed as call centre agents spend hours working in a sitting position without taking regular breaks.

The study showed that men experienced exhaustion. The findings show that $51.9 \%$ of call centre agents indicated that after work they usually felt worn out and weary. Exhaustion is a consequence of intense physical, affective and cognitive strain which stems from continuously being exposed to certain job demands (Demerouti \& Bakker, 2007). Employees feel overwhelmed and are unable to meet the constant job demands (Sowmya \& Panchanatham, 2011). Exhaustion is exacerbated by the excessive job demands of call centre work which include constant performance monitoring, high call volumes and constant customer interaction. This can lead to call centre agents being drained and having no energy to perform their work.

The results showed that $56.7 \%$ of women experienced voice hoarseness, $72.9 \%$ of women had a change in pitch, $79 \%$ had discomfort in the throat, and $59 \%$ had voice loss. The findings correspond with those of Hunter, Smith \& Tanner (2011), that women have a higher risk of voice problems due to higher fundamental frequency, laryngeal physiology and hormonal influences on the vocal fold. Call centre agents are at greater risk in developing vocal health problems owing to their job demands of constantly using their voices to assist clients. This is due to the heavy vocal load on the vocal cords.

The study showed that more women experienced optical health problems. The results showed that $92 \%$ of females experienced headaches related to optical health, and $89.4 \%$ indicated that they experienced irritated, sore or red eyes. The findings also showed that $78 \%$ experienced blurred vision, $88.6 \%$ had visual fatigue, $58.3 \%$ experienced dizziness related to optical health problems, and $81 \%$ experienced overall eye discomfort. A study conducted by Logaraj, Madhu Priya, Seetheraman \& Hedge (2013) found that dry eyes are more commonly encountered by women. Similar findings were reported in this study: more women indicated that they experienced headaches, visual fatigue, blurred vision, and red and sore eyes. Lorgaraj et al. (2014) also noted that being seated in front of a computer for a long time can cause reduced blinking by $60 \%$, leading to poor tear production and temporary stressing of the corneas, resulting in dry eyes. As call centre agents remain in a sitting position most of the day, while focusing on the computer monitor, VDU and DSE boards, their risk of developing optical health problems are higher. The work does not allow them to take regular short breaks to reduce eye discomfort or to focus their eyes on something else.

The study showed that female call centre agents were likely to experience anxiety, acute stress, and physical and behavioral stress symptoms. Job stress occurs when there is a conflict between the employee and the job demands placed on that employee (Colligan \& 
Higgins, 2005). Anxiety experienced by female call centre agents could be related to the ongoing pressures of reaching performance targets, as in most cases these are linked to annual monetary increases or bonuses. In this study, $20 \%$ of the female respondents indicated that they smoked 1-5 cigarettes and $13 \%$ indicated that they smoked 6-10 cigarettes daily. The study also shows that $27 \%$ of females had trouble sleeping at night. Of the female respondents, $27 \%$ indicated that they worked an evening shift from 18:00-22:00. According to Crew (2006), unsocial working hours affect sleeping patterns and are associated with health and safety problems which can increase job stress. Female call centre agents working the evening shift might find it stressful to balance work and family life as they would need childcare assistance at night and are not available to manage the household duties and support that is needed at home.

The study showed that men and women experienced low levels of MSD. Call centre agents indicated that they had experienced aches, pain and discomfort in various parts of their body in the past work week. The most frequently reported areas were pain and discomfort in the neck $(73 \%)$, in the shoulder $(73 \%)$ and in the lower back (74\%). This is similar to findings by Woods (2005). The most commonly affected areas are the neck, shoulders, back and eyes, due to prolonged time in a seated position, and postural alterations due to repetitive movements associated with constant and simultaneous use of the telephone and computer mouse, and with typing (Lacaze, Sacco, Rocha, Brangança Pereira \& Casarotto, 2010; Constancio, Moreti, Guerrieri \& Behlau, 2012). MSDs have been associated with computer screen work, and as call centre agents often use computer screens intensively and have fewer opportunities to take breaks from using the computer, they are at a higher risk of experiencing MSD (Australian Services Union, 2003).

\section{Practical implications}

This study yielded important results that contribute to the literature on call centres. The effects of the job characteristics and physical work environment on wellbeing imply that drastic measures should be put in place to improve the working environment in call centres as it impacts on the wellbeing of agents. In this regard focusing on what call centre agents perceive of their job characteristics and physical work environment is relevant and necessary to management of call centres and for future research. The study contributes to the literature and knowledge of the workplace environment and wellbeing of call centre agents.

\section{Limitations}

One of the limitations was finding call centres to participate in this study. Twenty companies with call centres were approached to participate and only four companies were willing to participate. The combined population size of all four call centres was 760 . Out of the population size only 275 respondents participated in the study, which is not a representation of the total call centres in the Cape Metropole. Another limitation was that only the job dimensions and critical psychological states sections of the Job Diagnostic Survey (JDS) was used to measure the core job characteristics and that the remaining sections on affective reactions to the job and individual growth and strength were not used as it did not relate to the study. It is possible that by not including all the sections of the JDS it affected the results of the study as more information could have been extracted to see the effect on wellbeing.

\section{Recommendations}

Call centre agents need to be cross-trained by in-house product specialist trainers at the organizations learning centres to handle various product related call types which will eliminate monotonous and routine work. Team leaders/supervisors should involve call centre agents in decision making with regards to work design, performance targets and monitoring. Call centre agents should be allowed to use their discretion when interacting with customers. Realistic and achievable performance targets need to be set by senior management. Performance monitoring should be done quarterly by direct supervisors and be based on team performance. Supervisors should be accessible by having an "open door" policy to provide support should call centre agents have work or personal concerns. It is important that supervisors give acknowledgement when call centre agents perform well at their job.

Call centre agents should be prompted at the beginning of their shift to adjust their workstations and chairs to their individual comfort level. Workstation should be designed to allow call centre agents to personalize their workspace and adequate storage facilities should be made available. Training should be given on how to adjust the screen controls and brightness on monitors, DSE and VSU's. Air and temperature control should be at a comfortable level to prevent employees from getting too cold or too hot.

The study focused on call centres in the Cape Metropole area in the Western Cape. A similar study needs to be conducted in other provinces to establish if similar findings will be revealed. 


\section{Conclusion}

The relationship between job characteristics, physical work environment and wellbeing can be viewed as an important factor that needs attention. The author recognises that there are essential job characteristics associated with call centre work but that there are elements of the job that can be redesigned to improve the wellbeing of call centre agents. The physical work environment is seen as an important factor in ensuring that call centre agents are comfortable and poor ergonomics can lead to poor wellbeing.

\section{Acknowledgements}

1. Competing interests. The authors declare that they had no financial or personal relationships that may have inappropriately influenced them in writing this article.

2. Authors' contributions. Mrs Noleen Miller (Cape Peninsula University of Technology) was responsible for the write-up of the background and literature review, methodology and reporting of the results. Professor Rozenda Hendrickse acted as research supervisor.

\section{References}

1. Abrahams, M. (2008). Globalisation and the call centre, International Sociology, 23 (2), pp. 197-210.

2. Aksin, Z., Armony, M., Mehrotra, V. (2007). The Modern Call Center: A Multi-Disciplinary Perspective on Operations Management Research, Production and Operations Management, 16 (6), pp. 665-688.

3. Amicus. (2006). Health and Safety in Call Centres. Retrieved March 5, 2012. Available at: http://www.amicustheunion.org.Anderson, E. \& Jansson, A. (2006). A call for learning - a model for developmental learning in call centres, Abstract presented at the $6^{\text {th }}$ UFHRD/AHRD Conference on Human Resource Development Research and Practice across Europe, Tilburg.

5. Banks, D. \& Roodt, G. (2011). The efficiency and quality dilemma: What drives South African call centre management performance indicators? South African Journal of Human Resource Management, 9 (1), pp. 1-17.

6. Barret, M. \& Davidson, M.J. (2006). Gender and Communication at Work. Aldershot: Ashgate.

7. Benner, C., Lewis, C. \& Omar, R. (2007). The South African Call Centre Industry: A Study of Strategy, Human Resource Practices and Performance. Retrieved on March 5, 2012. Available at: http://www.ilr.cornell.edu/globalcallcenter/research/upload/South-Africa-GCC-Report.pdf.

8. Bonds, A. (2006). Calling on Femininity? Gender, Call Centers, and Restructuring in the Rural America West, ACME: An International E-Journal for Critical Geographies, 5 (1), pp. 28-49.

9. Cappelli, P. (2008). Employment Relationships. New Models of White Collar Work. New York: Cambridge University Press.

10. Carrig, K. \& Wright, P. (2006). Building Profit Through Building People: Making Your Workforce The Strongest Link In The Value-Profit Chain. Alexandria, Virginia: Society for Human Resource Management.

11. Charbotel, B., Croidieu, S., Vohito, M., Guerin, A-C., Renaud, L., Jaussaud, J., Bourboul, C., Imbard, I., Ardiet, D., Bergeret, A. (2009). Working conditions in call-centers, the impact on employee health: a transversal study, International Archives of Occupational and Environmental Health, 82, pp. 747-756.

12. Colligan, T.W. \& Higgins, E.M. (2005). Workplace Stress: Etiology and Consequences, Journal of Workplace Behavioral Health, 21 (2), pp. 89-97.

13. Comcare. (2006). Call Centres: A Guide to Safe Work. Retrieved March 5, 2012. Available at: http://www.comcare.gov.au/_data/assets/pdf_file/0016/41281/call_centres_-A_guide_to_safe_work.pdf.

14. Constancio, S., Moreti, F., Guerrieri, A.C. \& Behlau, M. (2012). Body aches in call center operators and the relationship with voice use during work activities, Revista da Sociedade Brasileira de Fonoaudiologia, 17 (4), pp. 377-384.

15. Cooper, R., Boyko, C. \& Codinhoto, R. (2008). The effect of the physical environment on mental wellbeing. Stateof-Science Review SR-DR2. London: Government Office for Science.

16. Crew, S. (2006). A qualitative study on effects of working unsocial hours, Nursing Times, 102 (23), pp. 30-33.

17. Da Costa, B.R. \& Vieira, E.R. (2010). Risk Factors for Work-Related Musculoskeletal Disorders: A Systematic Review of Recent Longitudinal Studies, American Journal of Industrial Medicine, 53, pp. 285-323.

18. Danielsson, C.B. (2010). The Office An Explorative Study. Architectural Design's Impact on Health, Job Satisfaction and Wellbeing. Published PhD Dissertation, Royal Institute of Technology, Stockholm, Sweden.

19. Dean, A.M. \& Rainnie, A. (2008). Frontline employees' views on organizational factors that affect the delivery of service quality in call centers, Journal of Services Marketing, 23 (5), pp. 326-337.

20. Demerouti, E. \& Bakker, A.B. (2007). The Oldenburg Burnout Inventory: A Good Alternative to Measure Burnout (and Engagement). Retrieved March 5, 2012. Available at: http://www.beanmanaged.eu/pdf/articles/ arnoldbakker/article_arnold_bakker_173.pdf.

21. De Smet, P., Sans, S., Dramaix, M., Boulenguez, C., De Backer, G., Ferrario, M., Cesana, G., Houtman, I., Isacsson, O., Kittel, F., Ostergren, P.O., Peres, I., Pelfrene, E., Romon, M., Rosengren, A., Wilhelmsen, L. \& Kornitzer, M. (2005). Gender and regional differences in perceived job stress across Europe, European Journal of Public Health, 15 (5), pp. 536-545.

22. Deveroux, J., Hastings, R.R. \& Noone, S.J. (2009). Staff Stress and Burnout in Intellectual Disability Services: Work Stress Theory and Its Application, Journal of Applied Research in Intellectual Disabilities, 22 (6), pp. 561-573. 
23. Dreery, S.J. \& Kinnie, N. (2004). Call centres and human resource management: a cross-national perspective. New York: Palgrave MacMillan.

24. Elfering, A., Semmer, N.K. \& Grebner, S. (2005). Observer-assessed work stressors and patient safety: an event sampling study, Ergonomics, 49, pp. 457-469.

25. Fields, D.L. (2002). Taking the measure of work: a guide to validated scales for organizational research and diagnosis. Thousand Oaks, CA: Sage.

26. Garcia, D. \& Archer, T. (2012). When reaching our potential predicts low values: a longitudinal about performance and organizational values at call centres, Journal of Service Science and Management, 5, pp. 313-317.

27. Grant, A.M. (2008). The significance of task significance: Job performance effects, relational mechanisms, and boundary conditions, Journal of Applied Psychology, 93 (1), pp. 108-124.

28. Hackman, J.R. \& Oldham, G.R. (1975). Development of the Job Diagnostic Survey, Journal of Applied Psychology, 60 (2), p. 159.

29. Hannif, Z., McDonnell, A., Connell, J. \& Burgess, J. (2010). Working Time Flexibilities: a Paradox in Call Centres? Australian Bulletin of Labor, 36 (2), pp. 178-193.

30. Huang, Q. \& Gamble, J. (2015). Social expectations, gender and job satisfaction: Front-line employees in China's retail sector, Human Resource Management Journal, 25 (3), pp. 331-437.

31. Hauptfleisch, S. \& Uys, J.S. (2006). The experience of work in a call centre environment, SA Journal of Industrial Psychology, 32 (2), pp. 23-30.

32. Hedge, A. (1994). Cornell musculoskeletal discomfort questionnaire: Human Factors and Ergonomics Research Laboratory at Cornell University.

33. Herman Miller Inc. (2007). It's all about me: The benefits of personal control at work. Retrieved August $31,2012$. Available at: http://www.hermanmiller.com.

34. Hingst, R.D. (2006). Perceptions of working life in call centres, Journal of Management Practice, 7 (1), pp. 1-9.

35. Holman, D., Wall, T.D., Clegg, C.W., Sparrow, P. \& Howard, A. (2005). The Essentials of the new Workplace: a guide to the human impact of modern working practices. UK: John Wiley and Sons.

36. Hunter, E.J., Tanner, K. \& Smith, M.E. (2011). Gender differences affecting vocal health of women in vocally demanding careers, Logoped Phoniatr Vocal, 36 (3), p. 128.

37. Knoll Inc. (2010). A Call Center Case Study: The Impact of Workstation Design and Work Tools on Performance. Retrieved August 31, 2012. Available at: http://www.knoll.com/media/74/722/callcentercasestudy.pdf.

38. Korvajärvi, P. (2009). Attracting customers through practicing gender in call-centre work, Work Organization, Labor \& Globalisation, 3 (1), pp. 131-143.

39. Lacaze, D.H.D., Sacco, I.C.N., Rocha, L.E., Bragança Pereira, C.A. \& Casarotto, R.A. (2010). Stretching and joint mobilization exercises reduce call-center operators' musculoskeletal discomfort and fatigue, Clinics, 65 (7), pp. 657-662.

40. Latha, G. \& Panchanatham, N. (2010). Call Center Employees: Is Work Life Stress a Challenge, Sabaramuwa University Journal, 9 (1), pp. 1-9.

41. Lloyd, C. \& Payne, J. (2008). What is a skilled job? Exploring worker perceptions of skill in two UK call centres, SKOPE Research Paper, Cardiff University, 81, pp. 1-25.

42. Logaraj, M., Priya, V.M., Seetharaman, N. \& Hedge, S.K. (2013). Practice of ergonomic principles and computer vision syndrome (CVS) among undergraduate students in Chennai, National Journal of Medical Research, 3 (2), pp. 111-116.

43. Lunenberg, F.C. (2011). Motivating by enriching jobs to make them more interesting and challenging, International Journal of Management, Business, and Administration, 15 (1), pp. 1-11.

44. Lywood, J., Stone, M., Ekinci, Y. (2009). Customer experience and profitability: An application of the empathy rating index (ERIC) in UK call centres, Journal of Database Marketing and Customer Strategy Management, 16 (3), pp. 207-214.

45. Millard, N., Alcock, T. \& Butterworth, R. (2006). From agent to expert. The future of the contact centre advisor. A white paper from BT Global Services.

46. Möller, Y., Crous, F. \& Schepers, J.M. (2004). n Ondersoek na die persoonlikheidseinenskappe van inbelsentrumkonsultante, South African Journal of Industrial Psychology, 30 (2), pp. 74-84.

47. Mukhopadhyay, C., Basak, S., Gupta, S., Chawla, K. \& Bairy, I. (2008). A Comparative Analysis of Bacterial Growth with Earphone Use, Online Journal of Health and Allied Sciences, 7 (2), pp. 1-3. Retrieved on August 20, 2014. Available at: http://www.ojhas.org/issue26/2008-2-4.htm.

48. NIOSH. (2009). Generic Job Stress Questionnaire. Retrieved on March 5, 2012. Available at: http://www.cdc.gov/niosh/topics/workorg/tools/pdfs.

49. NIOSH. (2011). Reducing Noise Hazards For Call And Dispatch Center Operators. Retrieved on September 22 2013. Available at: http://www.cdc.gov/niosh/docs/wp-solutions/2011-210.pdf.

50. Norman, K., Tornquist, E. \& Toomingas, A. (2008). Working conditions in a selected sample of call centre companies in Sweden, International Journal of Occupational Safety and Ergonomics, 14 (2), pp. 177-194.

51. Palm, C. (2012). Management Control Systems and Perceived Stress In A Public Service Organization. Unpublished Master Thesis, UPPSALA University, Sweden. Retrieved on July 16, 2014. Available at: http://www.diva-portal.org/smash/get/diva2:548940/FULLTEXT01.pdf.

52. Patterson, M.G., Warr, P. \& West, M.A. (2004). Organizational climate and company productivity: the role of employee affect and employee level, Journal of Occupational and Organizational Psychology, 77, pp. 193-216. 
53. Paul, A.M. (2012). Workplace Woes: The 'Open' Office Is A Hotbed of Stress. Retrieved July 16, 2014. Available at: http://www.ideas.time.com/2012/08/15/why-the-open-office-is-a-hotbed-of-stress/.

54. Salahian, A., Oreizi, H.R., Abedi, M.R. \& Soltani, I. (2012). Co-worker/supervisor support and burnout, Interdisciplinary Journal of Contemporary Research in Business, 4 (1), pp. 141-148.

55. Schaufeli, W.B. \& Bakker, A.B. (2004). Job demands, job resources, and their relationship with burnout and engagement: a multi-sample study, Journal of Organizational Behavior, 25, pp. 293-315.

56. Schaufeli, W.B., Bakker, A.B. \& Van Rhenen, W. (2009). How changes in job demands and resources predict burnout, work engagement, and sickness absenteeism, Journal of Organizational Behavior, 30, pp. 893-917.

57. Seppänen, O., Fisk, W.J. \& Lei, Q.H. (2006). Effect of temperature on task performance in office environment. Helsinki University of Technology, Finland.

58. Shah, Y.A. (2013). Job Stress And Turnover Intention Among Call Centre Employers (A Relational Study). Unpublished dissertation submitted for Masters Philosophy, University of Kashmir, Hazratbal. Retrieved on October 20, 2014. Available at: http://www.dspaces.uok.edu.in/jspui/bistream/1/1391/1/YOUNIS\%20AHMAD\%20SHAH.pdf.

59. Sowmya, K.R. \& Panchanatham, N. (2011). Job Burnout: An outcome of organizational politics in banking sector, Far East Journal of Psychology and Business, 2 (1), pp. 49-58.

60. Sprigg, C.A. \& Jackson, P.R. (2006). Call centres as lean service environments: job related strain and the mediating role of work design, Journal of Occupational Health Psychology, 11 (2), pp. 197-212.

61. Sprigg, C.A., Smith, P.R. \& Jackson, P.R. (2003). Psychosocial risk factors in call centres: an evaluation of work design and well-being. Research paper prepared by the University of Sheffield, Health and Safety Laboratory and UMIST for the Health and Safety Executive. Research Report No. 169, HSMO, Norwich.

62. Subbarayalu, A.V. (2013). Occupational health problems of call center workers in India: A cross sectional study forcusing on gender differences, Journal of Management Science and Practice, 1 (2), pp. 63-70.

63. Suff, P., Reilly, P. \& Mercer, M. (2005). Your Call: Managing Reward and Performance in Call Centres. HR Network Paper MP51. Institute for Employment Studies.

64. Toomingas, A. \& Gavhed, D. (2008). Workstation layout and work postures at call centres in Sweden in relation to national law, EU-directives and ISO-standards, and to operators' comfort and symptoms, International Journal of Industrial Ergonomics, 38, pp. 1051-1061.

65. Vilkman, E. (2004). Occupational safety and health aspects of voice and speech professions, Folia Phoniatrica et Logopedica, 56, p. 220.

66. Visser, W.A. \& Rothmann, S. (2008). Exploring antecedents and consequences of burnout in a call centre, South African Journal of Industrial Psychology, 34 (2), pp. 79-87.

67. White, R. \& Roos, V. (2005). Core Competencies of a Call Centre Agent, South African Journal of Human Resource Management, 3 (2), pp. 41-47.

68. Wahlström, J. (2005). Ergonomics, musculoskeletal disorders and computer work, Occupational Medicine, 55, pp. $168-176$.

69. Woods, V. (2005). Musculoskeletal disorders and visual strain in intensive data processing workers, Occupational Medicine, 55, pp. 121-127. 


\section{Appendix}

Table 6. Pearsons correlations

\begin{tabular}{|c|c|c|c|c|c|c|c|c|c|c|c|c|c|c|c|c|c|c|c|}
\hline & SV & $\mathrm{JF}$ & $\mathrm{TI}$ & $\mathrm{AF}$ & TS & $A$ & SS & JD & PM & TAQ & WOL & MCC & $E$ & $\mathrm{VH}$ & $\mathrm{OH}$ & $\mathrm{AH}$ & AS & PBSS & MSD \\
\hline SV & 1 & & & & & & & & & & & & $-29^{\prime \prime}$ & & $-22^{\prime *}$ & & $-22^{* *}$ & $-.20^{* *}$ & \\
\hline $\mathrm{JF}$ & & 1 & & & & & & & & $.14^{*}$ & $.20^{*}$ & & $-28^{* \prime}$ & & & & & & $-.14^{*}$ \\
\hline TI & & $*$ & 1 & & & & & & & & $.17^{*}$ & & $-.23^{* *}$ & & & & $-.15^{*}$ & $-.19^{* *}$ & $-.15^{*}$ \\
\hline $\mathrm{AF}$ & & & & 1 & & & & & & $.15^{*}$ & $.16^{*}$ & & $-.17^{*}$ & & & & & & \\
\hline TS & & & & & 1 & & & & & $.19^{* *}$ & & & $-.27^{\prime \prime}$ & & $-.14^{*}$ & & $-21^{*}$ & & $-.16^{*}$ \\
\hline A & & & & & & 1 & & & & & $.25^{* *}$ & $.17^{*}$ & $-39^{* \prime}$ & $-.14^{*}$ & $-24^{\prime \prime}$ & $-.16^{*}$ & $-28^{* *}$ & $-27^{\prime \prime}$ & $-.21^{*}$ \\
\hline SS & & & & & & & 1 & & & $.19^{* \prime}$ & & & $-.31^{\prime \prime}$ & & $-.23^{* *}$ & & $-.15^{*}$ & $-.19^{* *}$ & $-.18^{*}$ \\
\hline JD & & & & & & & & 1 & & & $-32^{* *}$ & $-19^{* \prime}$ & $.37 *$ & $.19^{* *}$ & $.21^{*}$ & $.24 *$ & $.19^{*}$ & $.21^{* *}$ & $.24^{* *}$ \\
\hline PM & & & & & & & & & 1 & & $-.15^{*}$ & & & $.19^{* *}$ & & $.29^{* *}$ & & & \\
\hline TAQ & & & & $.15^{*}$ & $.19^{* \prime}$ & & $.19^{* \prime}$ & & & 1 & $.44^{* *}$ & $.38 *$ & & $-.15^{*}$ & $-.2^{* *}$ & -.04 & $-.22 *$ & & $-23^{* \prime}$ \\
\hline WOL & & $.20^{\prime \prime}$ & $.17^{\circ}$ & $.16^{*}$ & & $.25^{* \prime}$ & & $\begin{array}{l}.32 * \\
\end{array}$ & $-.15^{\circ}$ & $.44^{* *}$ & 1 & $.41^{*}$ & $\begin{array}{l}.25 " \\
\end{array}$ & & $-.15^{*}$ & $-.19^{* *}$ & $-24^{* *}$ & $-23^{* *}$ & $-.31^{*}$ \\
\hline MCC & & & & & & $.17^{\circ}$ & & $-.19^{* *}$ & & $.38^{\prime \prime}$ & $.41^{* *}$ & 1 & & $-.23^{* *}$ & $-.14^{*}$ & $-.18^{* *}$ & $-.25 *$ & -.17 & -.24 \\
\hline $\mathrm{E}$ & $-.29^{* *}$ & $-28 *$ & $-.23^{* *}$ & $-.17^{*}$ & $-.27^{* *}$ & $-39 *$ & $-.31^{\prime \prime}$ & $.37^{* *}$ & & -.08 & $-.25^{* \prime}$ & & 1 & & & & & & $-.39^{* *}$ \\
\hline $\mathrm{VH}$ & & & & & & $-.14^{*}$ & & $.19^{* *}$ & $.19^{\prime \prime}$ & $-.15^{*}$ & & $-23^{* \prime}$ & & 1 & & & & & \\
\hline $\mathrm{OH}$ & -.22" & & & & $-.14^{*}$ & $-.24^{* \prime}$ & $-25^{* \prime}$ & $.21^{* \prime}$ & & $-19^{\prime \prime}$ & $-.15^{*}$ & $-.14^{*}$ & & & 1 & & & & \\
\hline $\mathrm{AH}$ & & & & & & $-.16^{*}$ & & $.24^{* *}$ & $.29^{\prime \prime}$ & & $-19^{* *}$ & $-.18^{* \prime}$ & & & & 1 & & & \\
\hline AS & $-22^{*}$ & & $-.15^{*}$ & & $-.21^{*}$ & $-28^{\prime \prime}$ & $-.15^{*}$ & $.19^{* \prime \prime}$ & & - $-22^{\prime \prime}$ & $-24^{\prime \prime}$ & $-25^{*}$ & & & & & 1 & & \\
\hline PBSS & $-.20^{* *}$ & & $-.19^{* *}$ & & & $-.27^{* *}$ & $-19^{* *}$ & $.21^{* *}$ & & & $-23^{* \prime}$ & $-.17^{*}$ & & & & & & 1 & \\
\hline MSD & & $-.14^{*}$ & $-.15^{*}$ & & $-.16^{*}$ & $-.21^{\prime \prime}$ & $-.18^{*}$ & $.24^{* *}$ & & $-.23^{* \prime}$ & $-.31^{\prime \prime}$ & $-.24^{* *}$ & & & & & & & 1 \\
\hline
\end{tabular}

Notes: SV - Skill variety, JF - Job feedback, TI - Task identity, AF - Agent feedback, TS - Task significance, A - Autonomy, SS - Supervisor support, JD - Job demand, PM - Performance monitoring, W - Workstation, TAQ - Temperature and air quality, WOL - Workspace and office layout, MCC - Maintenance and adjustability of chairs, E - Exhaustion, VH - Vocal health problems, OH - Optical health problems, AH - Auditory health problems, AS - Acute stress, PBSS - Physical and behavioral stress symptoms, MSD - Musculoskeletal disorder. 